\title{
JOVANA DAVIDOVIC
}

\section{Displacement as Significant Collateral Harm in War}

\begin{abstract}
Traditionally, in deciding whether some strategy or action in war is proportionate and necessary and thus permissible both international law and just war theory focus exclusively on civilian deaths and the destruction of civilian infrastructure. I argue in this paper that any argument that can explain why we should care about collateral killing and damage to infrastructure can also explain why collateral displacement matters. I argue that displacement is a foreseeable nearproximate cause of lethal harm to civilians and is relevant for proportionality and necessity calculi. Accepting my argument has significant consequences for what we are permitted to do in war and for what obligations we have towards refugees that result from our actions in war.
\end{abstract}

Keywords: displacement; just war theory; laws of war; proportionality in bello, refugees.

\section{Introduction}

One in every 113 people is currently displaced. ${ }^{1}$ In 2014 nearly 60 million people were displaced due to armed conflict alone. ${ }^{2}$ According to the UNHCR's 2015 Annual Global Trend Report the rate at which people are fleeing persecution and armed conflict has risen from 6 a minute a decade ago to 24 a minute in 2015, the last year for which such data is available. Displacement due to armed conflict is clearly a pervasive and a significant phenomenon. In this paper I will argue that displacement is also a significant harm - the sort of harm that ought to play a role in our calculations of proportionality and necessity in war (in bello). ${ }^{3}$

Traditionally, in deciding whether some strategy or action in war is proportionate and necessary and thus permissible both international law and just war theory focus exclusively on civilian deaths and the destruction of civilian infrastructure. I contend that any argument that can justify why we ought to care about collateral killing, maiming and damage to infrastructure can also justify a requirement to care about collateral displacement. Accepting my argument will

1 UNHCR , 'UNHCR Global Trends Annual Report,' <http://www.unhcr.org/en-us/news/latest/2016/6/5763b65a4/ global-forced-displacement-hits-record-high.html> (Accessed: 4 October 2018).

2 The UNCHR Global Trends Annual Report states that the number of people forcibly displaced at the end of 2014 had risen to a staggering 59.5 million compared to 51.2 million a year earlier and 37.5 million a decade ago.

3 Jus in bello is traditionally distinguished from jus ad bellum and jus post bellum. Jus in bello conditions specify when an action in war is permissible. Jus ad bellum conditions specify what conditions need to be met for a war to be entered justly and jus post bellum discusses conditions that qualify what sorts of post war efforts are required of belligerents. 
have significant consequences for what we are permitted to do in war and for obligations we have towards refugees that result from our actions in war. I argue that when we use strategies in war that collaterally displace civilians, but would otherwise (traditionally considered) be proportionate and necessary, we ought to think of such actions as only conditionally proportionate and necessary. Meeting the conditions of proportionality and necessity, I argue, will often require having remedial processes in place; it will often require staffing refugee camps adjacent to the conflict and providing asylum for refugees resulting from the conflict.

I begin the argument, in section I, by explaining why displacement is a significant harm that should factor in our analyses of permissible actions in war. My argument parallels arguments that underpin the claim that destruction of civilian infrastructure should be considered in proportionality and necessity calculations. I also address some obvious objections to this contention including the claim that displacement is a significantly lesser harm than death and that thus it ought not to count in proportionality and necessity analyses.

Next, in section II, I turn to my main task - a defense of the claim that without remedial processes in place for displacement we will often fail to meet proportionality and necessity in bello. I explain why I think that even though displacement ought to factor in our analyses of in bello proportionality and necessity, displacement doesn't by itself make an action impermissible, nor does it in all cases require greater sacrifices on the part of the combatants. Instead, it requires a systematic remedial process to be put into place. I argue that if and when such a system is not in place at the beginning of the conflict and available for some time after, then creating excess refugees might make an otherwise proportionate and necessary action disproportionate or unnecessary and thus impermissible.

Finally, in section III, I discuss some further consequences of accepting my argument. I briefly discuss the consequences of my view for jus post bellum (post war justice). More centrally, I explain why I think my argument is relevant for both traditional and individualist accounts of just war.

A few preliminaries are required before I move on to my main argument. First, usually the term 'displaced persons' is used to refer to internally displaced persons and to distinguish such persons from refugees, who are by (legal) definition always displaced across borders. I use the term 'displaced persons' in this paper to refer to 'all persons or groups of persons who have been forced to flee, or leave, their homes or places of habitual residence as a result of armed conflict [or] internal strife,' and not only those that are internally displaced. ${ }^{4}$

4 According to UNHCR's definition of internally displaced persons, available at <http://www.unhcr.org/en-us/ internally-displaced-people.html> (Accessed: 8 October 2018). 
The notion of a displaced person so understood is broader than the notion of a refugee and encompasses it. It is narrower though than the traditional understanding of an internally displaced person who might be displaced for reasons other than armed conflict.

Second, my argument will proceed by assuming the traditional just war theory's approach to justice in war (jus in bello), rather than the individualist or revisionist accounts. ${ }^{5}$ Traditional just war theory is separated into jus ad bellum and jus in bello, where jus ad bellum conditions specify when it is just to enter the war and jus in bello conditions specify how one ought to fight the war. Traditionally, for our actions in war to be just they need to meet the conditions of discrimination, proportionality and necessity. In particular, our actions need to discriminate between civilians and combatants, impose harm on civilians only unintentionally, minimize the amount of this unintentional, but foreseeable harm and ensure that such harm is proportionate to our military aim. ${ }^{6}$ In addition, traditional just war theorists accept the so-called independence thesis - the view that unjust combatants can fight the war justly and that they do nothing wrong simply by fighting in an unjust war. Individualist scholars largely reject the independence thesis. They argue, among other things, that those lacking a just cause can almost never fight justly; after all whatever harm they impose on civilians would be in the pursuit of an unjust cause and would thus be disproportionate. This split in just war literature is substantive and important, and all things considered I think there are good reasons to side with individualist theorists. In spite of that the argument I provide here starts from traditionalist assumptions, including the independence thesis. I accept those assumptions for two reasons: first, because I am hopeful that my argument will be taken seriously by practitioners (who by and large operate within the realm of traditional just war theory) and second, because if approached this way my

5 One of the most prominent supporters of traditional just war theory is Michael Walzer, whose book Just and Unjust Wars revived the just war theory in the 1970s. Michael Walzer, Just and Unjust Wars: A Moral Argument with Historical Illustrations (New York, N.Y.: Basic Books, 1977).

6 The condition of necessity in bello has been interpreted in a number of ways. I provide here a condition of necessity that I think is the least controversial - namely that necessity condition requires that if we have a number of alternative strategies available to us to achieve some military advantage all of which meet the condition of proportionality, only the strategy that is least harmful is permissible. What exactly counts as least harmful varies among theorists. For some scholars, the action needs to be least harmful to combatants and civilians both, for others enemy force depletion can be a military advantage and thus not count against such an action. The Laws of War also use the notion of military necessity often as a broad term meaning 'justification for an action in war.' The Law of War Manual following scholars like Greenspan defines military necessity as 'the right to apply that amount and kind of force which is necessary to compel the submission of the enemy with the least possible expenditure of time, life, and money.' Morris Greenspan, The Modern Law of Land Warfare (Cambridge: Cambridge University Press, 1959), pp. 313-314. This would imply that in addition to civilians, limiting the harm to friendly combatants should also matter for analysis of necessity. Also see Jeff McMahan 'Proportionality and Necessity in Jus in Bello,' in Helen Frowe and Seth Lazar (eds.) Oxford Handbook of Ethics of War (Oxford: Oxford University Press 2016), 418-440; Jovana Davidovic, 'Proportionality and Necessity in War,' in Larry May (ed.) Cambridge Handbook of Just War (Cambridge: Cambridge University Press, 2017), 167-186. 
argument here can be mutatis mutandis extended to individualist theories. ${ }^{7}$ I discuss that claim in the last section.

Third, much of the debates in the ethics of migration literature focus on whether or not and why we have a duty to help refugees. The debates often center on question of whether one is entitled to exclude refugees or whether one has moral duties to help when someone else's basic human rights are violated and to what extent. While my argument here is primarily focused on showing how displacement ought to affect traditional just war theory and law of armed conflict, it is important to stress that given my argument here many of our duties to provide for refugees (at least to provide well-staffed and well-provisioned refugee camps) are not a matter of a duty to help, but a duty to remedy. Duties to remedy commonly arise from violations of duty not to harm and as such are as stringent as negative duties not to harm. In other words, if my argument here is right then some of our duties to provide for refugees are negative duties which are significantly more stringent and less easy to override than positive duties to help.

\section{Displacement as Significant Collateral Harm}

Commonly, when asking difficult questions about proportionality in war, just war theory focuses on civilian deaths (and less commonly on harm to civilian infrastructure), ignoring collateral displacement entirely. In fact, none of the central texts in just war theory that discuss proportionality and necessity in bello seem to consider collateral displacement to any extent in those discussions. From Michael Walzer's seminal Just and Unjust Wars, to more recent treatments of proportionality by scholars like Jeff McMahan, Saba Bazargan, Paul Gilbert, Thomas Hurka, and numerous others, time after time, collateral displacement is omitted from discussions of proportionality and necessity in bello. ${ }^{8}$ Two excellent handbooks on issues of ethics of war came out in recent times neither discussing nor mentioning collateral displacement as relevant for proportionality in war. ${ }^{9}$ Similarly, a recent volume called Weighing Lives

7 Ultimately, the hope for my argument here is that it will be relevant to both individualist and traditional just war theorists. It will be possible to make this argument relevant to individualist theory with a few revisions. For example, someone who is an individualist might argue that it matters whether the belligerents have an overall just cause or not - they might argue that if one doesn't have a just cause than all resulting displacement from any and all actions contributing to such cause would be unjust. A number of scholars have already argued for a position similar to this one, including for example Jovana Davidovic and Jennifer Kling. Jovana Davidovic, 'What do we owe refugees: jus ad bellum, duties to refugees from armed conflict zones and the right to asylum,' Journal of Global Ethics Special IssueRefugee Crisis: The Borders of Human Mobility, 12/3 (2016), 347-364. Jennifer Kling, 'Who owes what to refugees,' in Journal of Global Ethics Special Issue - Refugee Crisis: Borders of Human Mobility, 12/3 (2016), 327-346.

8 See Michael Walzer, Just and Unjust Wars (New York: Basic Books, 1977); Jeff McMahan, Killing in War (Oxford: Oxford University Press, 2009); Saba Bazargan, 'Compensation and Proportionality in War,' in Jens Ohlin, Larry May and Claire Finkelstein (eds.) Weighing Lives in War (Oxford: Oxford University Press, 2017); Paul Gilbert 'Proportionality in the Conduct of War,' Journal of Military Ethics, 4/2 (2005), 100-107, Thomas Hurka, 'Proportionality in the Morality of War,' Philosophy and Public Affairs, 33/1 (2005), 34-66.

9 May (ed) (2018); Frowe and Lazar (eds.) (2017). 
in War, which focused specifically on proportionality in war had not a single discussion of collateral displacement. ${ }^{10}$ This is the case to a different extent and for different reasons in individualist just war theory, in traditional just war theory, and in international law. ${ }^{11}$

In international law, for example, while displacement cannot be used as a tool of war, collateral displacement is barely addressed. Even though the latest version of the Department of Defense's (DoD's) Law of War Manual repeatedly professes that 'the protection of civilians against the harmful effects of hostilities is one of the main purposes of the law of war' it nonetheless continues (in line with previous versions) to explicitly state that the protection of civilians should focus on their deaths, injury and damage to civilian property. ${ }^{12}$ In fact, collateral displacement is never directly addressed in the entire document. ${ }^{13}$ Reasons why collateral displacement is not addressed are never explicitly mentioned, so one can only guess why such harm is ignored. Most likely it is because drafters of relevant documents think that displacement is just not the sort of harm that is significant enough that we ought to take it into consideration or because they worry that such harm is hard to reliably predict and estimate.

10 Probably closest to considering collateral displacement explicitly, Adil Haque suggests in his entry in this volume that remote, but foreseeable harms to civilians ought to be considered. Adil Ahmad Haque, 'A Theory of Jus in Bello Proportionality,' in eds. Jens Ohlin, Larry May and Claire Finkelstein Weighing Lives, (Oxford: Oxford University Press, 2017), 188-217, pp. 190-191.

11 While there are numerous revisions to the traditional just war theory - the version of the theory enshrined in the laws of war - most of the recent revisions are individualist in nature. Individualist just war accounts start by suggesting that the moral principles that apply in ordinary cases of self and other-defense ought to underpin our analyses of what can be done in war and when a war can be entered, i.e. our analyses of jus in bello and jus ad bellum. Individualists usually argue that one cannot justify collateral damage or killing enemy combatants as proportionate when their aim is unjust. But even individualist revisions of just war theory, which in most cases impose much more stringent limits on what can be done in war, also ignore collateral displacement to a large extent in their analyses of permissible actions in war. Most of the individualist literature on proportionality in war instead focuses on how much bodily or lethal harm one can impose on innocents and those who are minimally responsible in response to an unjustified threat. Individualist scholars working on issues of proportionality and necessity like Jeff McMahan, Saba Bazargan, Helen Frowe and others primarily focus thus on questions like how can a combatant know whether their war is just or unjust, i.e. whether they can engage in defensive harm and to what extent can a minimally responsible threat be harmed. See, Jeff McMahan, 'On the moral equality of combatants,' Journal of Political Philosophy 14/4 (2006); McMahan (2009); Hurka (2005); Saba Bazargan. 'Killing Minimally Responsible Threats,' Ethics 125/1 (2014), 114136; Helen Frowe, Defensive Killing: An Essay on War and Self-Defence. (Oxford: Oxford University Press, 2014); Victor Tadros, 'Duty and Liability', Utilitas 24/2 (2012), 259-277.

12 From here on out 'the Manual'. Department of Defense, 'Law of War Manual,' 2015, <http://archive.defense.gov/ pubs/Law-of-War-Manual-June-2015.pdf> (Accessed: 8 October 2018). The most recent version of the Manual from 2016 which contains some changes is also available at <https://www.documentcloud.org/documents/2997317-DoDLaw-of-War-Manual-June-2015-Updated-May-2016.html> (Accessed: 8 October 2018). Unless otherwise indicated article and page numbers are from the newest version of the Manual.

13 The Manual rightly acknowledges that forced displacement is against international norms and it discusses responsibilities of the occupying powers in cases when evacuations are necessary due to 'imperative military reasons.' The Manual, Art. 17.9.1 Displacement of the Civilian Population, 1026. 'The displacement of the civilian population shall not be ordered for reasons related to the conflict unless the security of the civilians involved or imperative military reasons so demand.' 


\section{Collateral Displacement in the Laws of War and Traditional Just War Theory}

The DoD's Law of War Manual is 'a guide for DoD personnel responsible for implementing the law of war and executing military operations. ${ }^{14}$ It addresses what may and may not be done in war. It starts answering such questions by looking at whether the condition of military necessity is met. The principle of military necessity acts as both a justifying condition and a limiting condition for any military action in war. ${ }^{15}$ The principle of military necessity as it is found in the Manual is conceptually distinct albeit a close cousin of the concept of in bello necessity, which we find in just war theory and that I will be discussing shortly. Military necessity, as it is found in the Manual 'justifies certain actions necessary to defeat the enemy as quickly and efficiently as possible. ${ }^{16}$ It is also, in my mind, a limiting condition since it requires that any particular action or strategy that are being considered bring us closer to military victory by offering some military advantage. Military necessity can justify a wide range of actions in war - in fact it justifies any action that also meets the conditions of distinction and proportionality. Those two are in turn, at least according to the Manual, results of finding a balance between the principles of military necessity, humanity and honor. The condition of humanity is considered an inverse of military necessity and a limiting condition on actions in war. ${ }^{17}$ It is seen as 'the source of the civilian population's immunity from being made the object of attack. ${ }^{18}$ According to The Manual the principle of humanity explains why we ought to provide 'fundamental safeguards for persons who fall into the hands of the enemy; protections for the civilian population and civilian objects; protections for military medical personnel, units, and transports; prohibitions on weapons that are calculated to cause superfluous injury [and] prohibitions on weapons that are inherently indiscriminate. ${ }^{19}$ The condition of proportionality also limits what can be done in the name of military necessity, by prohibiting any actions that are unreasonable or excessive. ${ }^{20}$

Neither military necessity, nor humanity, nor proportionality conditions (as they are understood in the Manual) require that collateral displacement be considered in assessing whether the condition has been met. While deliberate displacement as a tool for ethnic cleansing is clearly prohibited, collateral

14 'DoD announces update to the DoD Law of War Manual,' <https://www.defense.gov/News/News-Releases/NewsRelease-View/Article/852738/dod-announces-update-to-the-dod-law-of-war-manual> (Accessed: 8 October 2018).

15 I ought to mention that the language in the Manual explicitly states that the military necessity is a justifying principle, but it becomes obvious from the language this principle is properly speaking both a justifying and a limiting condition.

16 The Manual, Art. 2.1.2.3, 51.

17 The notion that principle of humanity is an 'inverse' of the principle of military necessity is not my terminology. I take it that the Manual drafters have in mind that while principle of necessity justifies, the principle of humanity limits.

18 The Manual, Art. 2.3.1, 59 .

19 The Manual, Art. 2.3.2, 59-60.

20 The Manual, Art. 2.1.2.3, 51. 
displacement is ignored. As I have already indicated, this might very well be because military practitioners and drafters of relevant documents including the Manual just assume that the harm of displacement is not significant enough to warrant particular consideration and that it is certainly not significant enough to give us reasons to require a strategy that might risk greater harm to our combatants. Alternatively, or in addition, they might think that such harm is also hard to reliably predict. I think they are wrong on both counts.

There are good reasons to think that displacement is a significant harm that can be reliably quantified. Displacement harm should be seriously considered in our assessments of permissibility of actions in war. Not only is the harm of displacement significant, it is also divisible and remediable. ${ }^{21} \mathrm{I}$ turn to reasons in support of this view next.

\section{Displacement as a Serious and Significant Harm in Bello}

Over two-thirds of all refugees live in protracted refugee situations. Those refugees that remain in camps (which is close to a half of all refugees) spend an average of 17 years in a camp. ${ }^{22}$ Most refugee camps are significantly understaffed and have very limited resources. Many refugees also live in protracted refugee situations outside of camps. For example, Jordan currently is home to over 1.4 million Syrian refugees, only 20\% of which live in formal (usually UNHCR-run) refugee camps. Many others live in unofficial tented settlements, which are in most cases significantly worse off regarding resources and access to health care, food and clean water. ${ }^{23}$ According to one observer the conditions in such settlements in the north-eastern Marfaq region of Jordan (which is home to 150,00 refugees) 'are undeniably harsh [...] with high temperatures during the day and extreme cold at night [...] especially [visible are] the lack of sanitation and medical care in the camps. ${ }^{24}$

Illnesses and malnutrition are common in camps. In fact, because these camps are understaffed (or unstaffed) and have limited (or no) resources most basic needs and rights of refugees living in them are not met. Many refugees die or suffer debilitating illnesses as refugees. Others die just trying to make it to a safe place. For example, 3,80o displaced persons (many of whom were children)

21 For most other types of harm one faces decisions about in war the decisions are dichotomous: either one risks their forces or one risks the lives of enemy civilians. The decisions about displacement harm need not be dichotomous - we can often make choices that split the harm in an acceptable way. In many cases displacement can be minimized by expending further resources or by minimally increasing the risk of harm to one's combatants, which I will argue can be justified. Yet this is not required by international laws governing behavior in war; it is not required by traditional just war analysis, or by individualist theories of just war.

22 Serena Parekh, Refugees and the Ethics of Forced Displacement, (New York: Routledge, 2017), p. 3.

23 Naina Bajekal, 'Inside the Syrian refugee camps where childhood doesn't exist,' Time Magazine, Aug 2015, <http:// time.com/3987244/syrian-refugees-mafraq-jordan/> (Accessed: 8 October 2018).

24 Ibid. 
drowned in the Mediterranean in 2016. ${ }^{25}$ The mortality rates in refugee camps are often 30-40 times higher than during peacetime in the same region. In other words, refugees are 30-40 times more likely to die as a result of being a refugee from an armed conflict in an understaffed camp with limited resources than during peacetime. ${ }^{26}$ While the data discussing increased mortality and morbidity rates in refugee camps is readily available, it is somewhat sporadic; and in particular it is not readily available for all conflicts or all camps. In what follows I lay out some of the available data, which is primarily from UNHCR or government-run camps. It is important to stress that statistics are unavailable, but very likely significantly worse, for the unofficial settlements.

Consider, for example, CDC's (Center for Disease Control) mortality and morbidity data for refugees living in camps during and after the Rwandan crisis. ${ }^{27}$ This data shows that during the worst of the crisis there were 980 cases of diarrheal illness per 100,ooo people per week in the Ngozi camp. ${ }^{28}$ The average deaths were up to 8 per day per 10,000 as compared to non-emergency 0.5 per 10,000 per day in the same region. That means that a refugee in that camp was 16 times more likely to die than if they were not a refugee in an understaffed camp with limited resources. Most of those deaths were attributed to illness and malnutrition, which are obviously remediable with the right resources. The same CDC study also compared the death rates for refugees in different camps. In particular, it compared the mortality and morbidity rates of refugees in camps in Burundi to those that were in then Zaire (now the Democratic Republic of Congo). It found that the

[d]eath rates among refugee populations may be substantially increased when exodus is rapid and large numbers of persons are displaced. During nonemergency situations, the daily CMR [crude mortality rate] in developing countries is 0.5 per 10,000 persons. The death rates in Zaire in refugee camps were at 34-54 deaths per 10,000 per day [and] were among the highest [...] documented during recent refugee emergencies. [T]hose among refugees in Burundi were similar to those recorded in border camps in Thailand in 1979 (10.6 per 10,000 per day), in Somalia in 1980 (10.1 per 10,000 per day), and in Ethiopia in 1991 (4.7 per 10,000 per day). In Zaire, a high proportion (initially 90\%) of deaths occurred outside health-

25 CNN, 'Mediterranean Migrant Crisis Visual Guide', October 2016, <http://www.cnn.com/2016/10/26/europe/ mediterranean-migrant-crisis-visual-guide-trnd/> (Accessed: 8 October 2018).

26 In the rest of this paper, whenever I use the phrase are ' $x$ times more likely to die' I mean ' $x$ times more likely to die than the members of the same population in the same region during peacetime.'

27 Center for Disease Control, 'Morbidity and Mortality Surveillance in Burundi and Zaire during the 1994 Rwandan Crisis,' <https://www.cdc.gov/mmwr/preview/mmwrhtml/ooo40202.htm> (Accessed: 17 November 2017).

28 Ibid. 
care facilities, indicating either that health-care services were not accessible to a high proportion of severely ill persons or services at clinic sites were exceeded by demands. This finding emphasizes the need for establishing community rehydration programs at the beginning of the emergency phase. ${ }^{29}$

This means that according to this study any given refugee is about 20 to 30 times more likely to die due to being a refugee during the worst parts of the crisis. For some crises and for some periods of such crises the mortality rates can be as much as 60-100 times higher for a refugee as a result of being a refugee in a camp without appropriate resources. Other studies have the mortality rates at 40 times higher. ${ }^{30}$ This coupled with an increased chance of dying during migration (which is often significantly higher in the first few days) means that one can easily estimate the percentage of people that will die as a result of displacement. Displacement in armed conflicts without camps with adequate staff and resources predictably and reliably leads to death from diarrheal diseases, acute respiratory infections (ARIs), malarial disease and other preventable causes.

All of this translates into the claim that often in war we commit acts that we know will (without appropriate and timely remedies) cause the death of some significant number of civilians. Thus, one good reason to take displacement seriously is because it translates into lethal harm. And it translates into lethal harm in a predictable way.

But it is not just the increased likelihood of lethal harm that explains why displacement is a serious and significant harm. Effectively losing 17 years of one's life, which in many cases living in a camp like this can be understood as is also a significant harm. Suffering debilitating illness can also be a significant harm. In addition to it being a significant harm in the sense that it is serious, such harm is also significant for assessing permissibility of actions in war, I will argue.

My argument for seeing displacement as a significant harm for in bello analysis is meant to parallel arguments defending the claim that the destruction

29 Ibid.

30 M.J. Toole and R.J. Waldman, 'An Analysis of Mortality Trends Among refugee Populations in Somalia, Sudan and Thailand,' Bulletin of the World Health Organization, 66/2 (1988), 237-247, <http://apps.who.int/iris/ bitstream/10665/48418/1/bulletin_1988_66(2)_237-247.pdf> (Accessed: 8 October 2018). Another study goes on to specify that it is not surprising that ' $[\mathrm{c}$ ]ommunicable diseases are the predominant causes of morbidity and mortality during the emergency phase of encampment. Timely and effective management of communicable diseases including malnutrition and trauma are crucial to avoid high mortality amongst refugees, coupled with the provision of essential requirements and services such as water, sanitation, food, shelter and immunisation', Orach, C.G., 'Morbidity and Mortality among southern Sudanese in Koboko refugee camps, Arua District Uganda,' East African Medical Journal, 76/4 (1999): 195-199, <https://www.ncbi.nlm.nih.gov/pubmed/10442100> (Accessed: 8 October 2018). 
of civilian property and civilian infrastructure ought to be seen as significant in our analyses of proportionality and necessity in war. Traditionally, we don't prohibit such destruction and we don't require significant military advantage to justify such damage simply because such attacks increase the risk of direct or kinetic lethal harm to civilians. ${ }^{31}$ The primary reason why damage to civilian property is taken seriously is not the increased likelihood that civilians could be present there, that consideration should be exhausted by our analyses of how many civilians are present and what is the risk of kinetic lethal harm to them. One of the main reasons we care about civilian property and infrastructure is its use to civilians. In other words, even in absence of civilians near a civilian-use property or civilian infrastructure, damage or destruction to such property is considered a relevant and significant harm for our analyses of proportionality - the sort of harm that needs to be outweighed by some weighty military advantage. There are a number of reasons why this would be the case, but the most obvious one that can also explain the extra weightiness of a hospital or a water treatment facility vs. some other civilian building, is that such harm has indirect but quantifiable with a high level of certainty relationship with significant including lethal harm to civilians. Simply put the prohibition on destruction of civilian buildings like hospitals and water treatment plants emerges out of the fact that such destruction will foreseeably result in civilian deaths that we can reliably quantify.

Similarly, displacement without provision for displaced individuals also leads to an increased number of deaths from illness (malaria, diarrheal, ARIs), which can be reliably predicted and estimated. If our reasons for prohibiting destruction of civilian infrastructure are grounded in the predictable increase in civilian deaths, we have no reason to exclude displacement as a significant harm. The increase in the risk of lethal harm is just as proximate in cases of displacement as in cases when civilian-use infrastructure is damaged or destroyed. Displacement and the destruction of civilian infrastructure are comparably (or equivalently) causally related to lethal civilian harm. In both cases, the original action is in a near-proximate relationship with lethal harm to civilians. The actions are near-proximate in the sense that in both cases the causal relationship can be broken by an intervention remedying the original harm and in both cases the predictability regarding the consequences of our actions is similar. ${ }^{32}$

31 The notion of kinetic action in war or kinetic harm has been used in a number of ways - some have used it as a euphemism for any action in war that causes lethal harm, others have used it is in contract to cyber actions in war. I use it to distinguish direct harm to civilians that is caused by weapons or ammunition harming bodies directly.

32 In fact, in many cases the (lethal) harm that results from destruction of civilian infrastructure is mediated through the fact that civilians are collaterally displaced due to a lack of basic resources when infrastructure is damaged. This in turn means that we would need to think hard about how to engage in such calculations without 'double-counting' the harm that a particular action causes, but the difficulty is no greater than similar difficulties in estimating who is likely to die and as a result of what when assessing the harm of destroying infrastructure. 
Similarly, other displacement harms - like living for 17 years in a refugee camp where one's basic human needs are not met - are also significant harms. The significance of such harms could possibly be understood and analyzed though a parallel to the harms of maiming and significant injury to civilians. I do not engage in such analysis here, primarily since my main aim is to show that at least some harms of displacement can be and should be considered in in bello proportionality and necessity calculations. I turn to the consequences of this central claim: that we ought to take collateral displacement seriously in our calculations of proportionality and necessity in bello, in the next section. Before I do, I want to quickly address two possible objections to my argument.

First, given that I am building an argument relying on a parallel to reasons why civilian property is off limits during war, and given that I will be concluding that we ought to provide for the displaced individuals in some cases as a matter of justice in war, one might think that making this argument then also commits me to saying that the destruction of civilian property gives rise to a responsibility to rebuild. It might even commit me to saying that we are not permitted to collaterally damage civilian infrastructure without planning to rebuild it. To start, rebuilding is in fact a commonly accepted condition for post bellum justice. In other words, I am not sure that if this was a consequence of my view, we ought to think of it as an objection in the first place. But secondly, there are good reasons to think that I need not be committed to the same/similar remedy when it comes to damage to infrastructure as when it comes to collateral displacement. In other words, the parallels in the underlying arguments for the prohibition of actions that cause displacement and those that cause damage to infrastructure need not commit us to parallels in the way violations of such prohibitions are remedied or addressed. This is for a number of reasons. First, displacement and destruction of infrastructure are in practice often related in such a way that destruction of infrastructure leads to displacement, thus it might be the case that remedying one is required to remedy both. Second, while the repair of infrastructure might not need to be undertaken parallel to the war effort, the provisions for displaced persons almost always do. Finally, there is likely a difference in the practicality of possible remedies. For example, trying to rebuild while the war is ongoing might be pointless, given that the same property might be destroyed again and given that rebuilding might endanger those that attempt to rebuild.

The second objection, common especially among military practitioners, is that death is a much greater harm than displacement and that that is the reason why we ought to focus on collateral lethal harm and not things like collateral displacement. This objection is often supported or accompanied by the claim 
that we cannot know and do not know the long-term consequences of such displacement and that because many of the worst consequences are mediated via lack of resources and staffing in camps, we cannot be held responsible for all the long-term harm. To start, the last part of the objection really only addresses the question whether the long-term harm should be attributable to the war or particular actions in war. The immediate increase in lethal harm is not susceptible to such objections. My argument established that some number/percentage of displaced persons will die and predictably so as a result of our actions that displaced them. While it is the case that most of those deaths (not all) are caused proximately by illness, that illness is a foreseeable result of displacement. Imagine a parallel scenario where I have in the pursuit of my aims caused you to fall onto a busy interstate and be hit by a car - it is certainly the case that we would say that the car killed you, but it would be odd to hold the car or even its driver responsible (assuming they were driving at a reasonable speed, weren't distracted by their phone, etc.). More importantly, remember that my argument was based on an appeal to the reasons that explain why collateral damage to civilian infrastructure is prohibited. If objections such as the above one work, they work to show not only that displacement is not a significant enough of a harm, but also that destruction to civilian infrastructure is not significant enough to take into consideration in our analyses of what is permissible in war. ${ }^{33}$

Ultimately, there are good reasons to take both morbidity and mortality rates seriously as indicators of displacement harm. There are also good reasons to think that when we speak of lethal harm in war, whether it be via direct kinetic action, or mediated via destruction of property or via displacement, minimizing harm to civilians is focused on lowering predictable increases in mortality (and possibly morbidity) rates. Even if one is sympathetic to saying we are really only after minimizing lethal harm to civilians the argument above is relevant. It is incumbent on those that reject the argument to justify the claim that there is a morally salient difference between kinetic lethal harm and lethal harm mediated via displacement, both of which are ultimately evaluated in terms of the likelihood of such harm, which is in turn dependent on a range of different but similarly predictable factors.

As a result of these objections and with a desire to develop an argument that practitioners take seriously the argument that follows (regarding in bello proportionality and necessity) will focus on the minimal claim that displacement

33 I should also note that possible variations of this objection that include the inability to compare military advantage to displacement harm, would also be objections against comparability of military advantage to collateral damage to infrastructure, and if working within traditional theories of war, even objections against comparability of military advantage to human lives. 
is a foreseeable near-proximate cause of lethal harm to civilians and is relevant for proportionality and necessity calculi in cases when it leads to lethal harm. I think that both as a matter of morality and as a matter of interpretation of relevant laws we ought to also think about the other significant harms to civilians, not simply lethal harm. But for the above reasons, I only focus on lethal harm. If one accepts my further claims regarding non-lethal but serious harms the argument I provide below is that much more salient. If one thinks lethal harm is the only harm we should care about the argument that follows still results in significant changes to the way we ought to behave. With all of this in mind, I now turn to the consequences of the view that we ought to take displacement seriously in evaluations of proportionality and necessity in bello.

\section{Displacement and Proportionality and Necessity in Bello}

Given that I am working within the traditional just war theory framework I focus here on the extent to which we ought to take collateral displacement seriously in our analyses of proportionality and necessity in war independent of the justness of one's cause. I think this is particularly important, because a) most sides think their war is just and b) many scholars still think that jus ad bellum and jus in bello are independent. In fact, as I pointed out, relevant international law still operates under the assumption of the independence thesis. That being said I will in the last section quickly lay out the consequence of my view for someone who thinks that overall justness of one's cause for war affects proportionality and necessity in bello.

\section{Proportionality}

Traditional proportionality in bello condition asks that strategists and combatants compare the number of foreseeable but unintended civilian deaths to the military advantage one is seeking. Such military advantage is not assessed by its likelihood of, for example, limiting future harm to civilians (that might only be the case in humanitarian wars); whether and to what extent some action is militarily advantageous is instead assessed by looking at how much closer it gets us to military victory. I argue that at times an action, which seems proportionate, based on the likelihood of collateral damage, traditionally understood, might become disproportionate, if displacement is considered.

Consider the following scenario: a military contingent needs to cross a river and take control of the enemy's ammunition storage. The proposed strategy to do so involves likely collaterally displacing 2500 civilians and risking the lives of another 10 civilians. Imagine further that the person in charge using traditional proportionality analysis has rightly assessed that the 70\% risk of direct lethal harm to the 10 civilians in the area is worth the military advantage 
one would achieve by getting across the river and taking control of the enemy's large ammunition storage. Further assume that she (the decision maker) has also rightly estimated that were the number of civilians with the same risk of harm 20 (so 10 extra civilians) our action would be disproportionate and thus impermissible. In other words, we have assessed that:

10 civilians at $70 \%$ risk of lethal harm $<$ military advantage $=$ permissible ${ }^{34}$;

20 civilians at $70 \%$ risk of lethal harm $>$ military advantage $=$ impermissible.

If my argument above in favor of displacement being translatable into lethal harm is correct, then we can achieve the same weightiness on the left side of the equation if we displace a significant number of people and we do not provide basic resources for them. If we know that, as in our hypothetical case, 2500 people will be displaced as a result of our actions or strategies and we know that an average refugee camp in the region has (as many others have in the past) a 40 times increase in mortality, then if the average rate of death for non-displaced persons in the region is 0.5 per 10,000 per day and if we are displacing 2500 people, then there will be 5 people per day dying as a result of our actions. So, after 2 days 10 people will die as a result of our actions effectively pushing the above calculus into the impermissible range. The reliability of this calculus is, it seems to me, same or higher than the reliability of the percentage chance that a civilian walking nearby will die as a result of a bomb blast, simply because of the types of information one needs access to so as to make such estimates. Also keep in mind that the statistics for many refugee camps during the worst parts of the crises are significantly worse than my assumption of a 40-fold increase in mortality rates. Furthermore, the statistics for non-UNHCR camps where most refugees end up are also likely significantly worse. Further, many displaced persons die during migration. In other words, it seems that even with a modest assumption that everyone makes it to an UNHCR-run camp and only stays there a bit before moving on to a more secure place, a relatively small number of people being displaced could significantly alter our proportionality calculation. 35

Two important points need to be made at this stage. First, there is a limit to a number of days or the extent of displacement harms that are fairly attributed to an action in war that resulted in such displacement. But whatever that number is it will be significantly higher than 2 days and probably significantly higher

34 Assuming all other conditions (other than proportionality) have been met.

35 Imagine only 100 people being displaced. At 40 times increase in mortality, we will have 0.2 people dying a day. It would take 50 days in a poorly staffed camp to also reach mortality rate of 10 . 
than a month. I take it that the sorts of factors that would affect where to draw such a line will primarily focus on the contributing causal factors for deaths. For example, if the enemy government is preventing food and medical supplies from arriving at the camp, that might be a reason to argue that that is now the relevant near-proximate cause and a significant intervening cause and that it lessens our responsibility for the resulting lethal harm. Secondly, and much more importantly, I am not suggesting that we engage in these sorts of analyses in the midst of an action in war. ${ }^{36}$ Just like we do not expect our strategists to analyze likelihoods of civilians dying from a bomb on the spot, but let them rely on blast radiuses which analyze damage to human bodies and buildings to provide such decision-makers with an estimate of how many lives will likely be taken by a particular ordinance, similarly, I am suggesting that the fact that calculi such as the one I have provided can be done should act as reason to consider displacement seriously and to, as I will shortly argue, provide safe and well-staffed refugee camps in order to broaden one's range of permissible actions in war. In other words, I am suggesting that from the fact that such algorithm is justified it follows that displacement matters for proportionality in bello. ${ }^{37}$

I take it that in many cases of displacement we can with high certainty estimate how many people will die as a result of such displacement. The particularly interesting thing about displacement is that unlike direct lethal harm and much more like infrastructure destruction it is a harm that can be remedied and divided. This in turn means that in the above case we can estimate what number of added people displaced would make an action impermissible and we can either choose not to engage in such an action (if it will displace more than that amount) or remedy the 'disproportionate' harm, namely the excess displacement harm, by providing for the resulting refugees. This in turn means that staffing refugee camps in the area and providing a quick path to asylum in cases when the war has made an area unlivable for some significant number of years and providing assistance to surrounding countries (admitting those displaced) can all be ways to make an action which is only conditionally proportionate and thus only conditionally permissible actually proportionate and permissible.

There are a number of interesting consequences and questions that arise out of my view. First, it is not uncommon for a military to inform civilians in

36 This is for two reasons. First, because requiring such difficult calculations in war could act as a reason not to take them seriously - because doing such calculations on the spot might simply not be plausible. Second, because such calculations often leave us with an overall feeling of unease.

37 Algorithm: likelihood of dying in a camp for camp-related reasons expressed as a fraction multiplied by the number of people displaced and further multiplied by the number of days in a camp at the same increased mortality rate. 
the region that they will be bombing or engaging in some form of dangerous military operations in that they are being given an opportunity to escape/leave. One might think that such displacement is intended and thus isn't the sort of displacement my argument addresses. I think that's wrong. It seems rather obvious to me that it is cases like this one as much as collateral displacement resulting, for example, from actually engaging in dangerous activities, that ought to count. In fact, in cases such as this, statistics regarding the number of people that will be displaced are significantly easier to figure out.

Second, it is important to note that even when they don't looklike it, calculations of lethal harm, both when they result from kinetic military actions and when they result from displacement, are ultimately estimated based on likelihoods of lethal harm and reliability regarding such assessment. Even when the end user or a decision maker in a kinetic action operates as if the certainty of civilian death is $100 \%$, as in cases of targeted killings when all civilians within a certain blast radius are counted as certain foreseeable casualties, we are in reality still operating with only some likelihood of lethal harm. ${ }^{38}$ So we ought not to worry about differences in the kind of information with which one operates to make lethal harm assessments.

Third, there are interesting questions about cases when migration gets used by enemy forces to move combatants or equipment (by using migrants as human shields for example). In particular, how can one or should one provide migration-safe routes in those cases? I think there are good reasons to think that one ought not to make such migration routes less safe, but that one is not responsible in the same way or for the same reasons for making such migration routes safe. My reasons for thinking this emerge out of considerations similar to those above that discussed the lessening of responsibility in cases when enemy forces block staff and resources from arriving in camps.

Fourth, I want to stress that as with collateral property damage, it doesn't follow from my argument that when making a choice between lethal harm resulting from displacement and lethal harm resulting from kinetic actions that we ought to, for example, kill more to displace less. For example, even though I argued in my hypothetical example that the risk of lethal harm for 50 displaced persons equals high likelihood of a kinetic lethal harm to 1 civilian it doesn't follow from that that we ought to kill 2 people instead of displacing $110 .{ }^{39}$ The

38 In other words, even when we act as if there is a 100\% chance of killing some civilians, that is usually just shorthand based on (as in case of UAV targeted killing) built-in facts about the bombs one is using, their blast radius and facts about the human body. This is important to note, so as to avoid the suggestion that displacement harm that leads to lethal harm being somehow less certain. In other words, it is not the case that the only lethal harm to civilians that we consider as relevant has a $100 \%$ certainty attached to it.

39 See previous calculation and algorithm in footnote 317. 
fact that one can make sense of why displacement is a significant harm in terms of lethal harm, does not commit one to saying that this is interchangeable harm. This is partly because of the expressive harm in civilian collateral deaths. More importantly, if I am right that displacement harms can be remedied (like harms to property and in fact more effectively) then we have at least one positive reason to suggest that if our actions will kill one civilian or displace some number of civilians (whose displacement translates into a high likelihood of one death as a result of such a displacement) we ought to displace the civilians and provide remedies. Simply put, all else being equal, if we can impose two comparable harms, one of which is remediable and the other is not, we ought to impose the one that is easier to remedy. This is partly because we have a duty not only not to intentionally cause harm to civilians of any kind, but also if Michael Walzer is right we also have, what he calls a duty emerging from the doctrine of double intent; namely a duty to not only not intend to harm civilians, but also a duty to intend to minimize unintended, but foreseeable harms. It seems to me that displacing civilians and providing remedies does that better than killing one civilian so as not to displace 40 .

Fifth, as I had already suggested, I do not think that the harm of death is the only harm we ought to consider in our analyses of displacement, but what the above shows is that even if we were only considering lethal harm we nonetheless need to consider displacement in our analyses of proportionality, and, in many cases, such consideration will take away our permission to engage in certain strategies unless we have a systematic way of providing for the resulting refugees. If we take other harm like increased morbidity and having basic human rights violated for a whole generation seriously we will end up with an even higher hurdle for many actions in war and a further reason to systematically provide for resulting excess refugees.

\section{Necessity}

Displacement should also factor in our assessments of necessity in bello. The just war theory's in bello necessity condition is closely related to, but conceptually separate from, the law of war's condition of military necessity discussed earlier. As we saw, the principle of military necessity is usually seen as primarily a justifying condition. The just war theory's in bello necessity condition is primarily a limiting condition, which requires the use of minimal force. In cases when a number of strategies are available (as is almost always the case) the in bello necessity condition requires that the least harmful alternative be undertaken. Usually this means that if it would be militarily advantageous for the troops to cross a bridge and there are two alternatives available to them - one which increases the risk of civilian casualties greatly and the other 
which only increases the risk of civilian casualties slightly, while for example also costing more in equipment loss, even if both of the alternatives meet the condition of proportionality, it would be morally and legally impermissible to use the strategy with a higher risk to civilians. I believe, in line with arguments presented up until now, that collateral displacement should be also taken into account in evaluating alternatives and deciding whether the necessity condition has been met.

For example, when the harm of a particular action can be divided between one side's combatants or resources and the other side's civilians (even when the harm is one of displacement) it ought to be divided. Combatants ought to in some circumstances take greater risks to limit displacement. I do not think this is always the case and the morally salient conditions that affect our analysis of the extent to which the harm of displacement ought to be considered against force protection are numerous. They include the extent of harm one could avoid and the cost to our military aim. But importantly, the way this calculus is undertaken - i.e. when force protection beats out civilian protection should be similar in cases of kinetic lethal harm and displacement-caused lethal harm.

Displacement in calculations of necessity should then be considered similarly to the way it is considered for proportionality, namely as a function of the increase in mortality and morbidity. In cases when one of the alternatives (alternative a) seems preferable over another alternative (alternative $b$ ) without taking displacement into consideration, then in cases when alternative $b$ would have been preferable over alternative a considering displacement, one violates the in bello necessity condition if one adopts alternative $a$. Depending on the extent of that violation, one can in some cases meet the condition by once again having systemic mechanisms in place for providing for refugees such that the increase in morbidity and mortality is lower making alternative $a$ once again preferable. Alternatively, or in addition, in many cases, one can take some of the risk on themselves.

\section{Final Remarks and Applicability of the Argument to Individualist Just War Theories}

Ultimately, I have argued here that if we take collateral displacement seriously then what is expected of us in war will be significantly altered. I have argued that traditional just war theory has to be committed to taking collateral displacement seriously and that just war scholars and military practitioners have largely ignored that. On most views, just war theory has very little to nothing to say about collateral displacement or our responsibilities towards refugees. I have argued that is a significant omission. ${ }^{40}$ Just war theory not only has the tools

40 Significant both theoretically and practically. 
to make sense of our responsibilities towards refugees from armed conflicts, but most just war theorists ought to, for reasons of coherence, be committed to taking collateral displacement seriously. Doing so, I suggest, will have significant consequences for what we see ourselves as being committed to morally and in practice as just war scholars and military practitioners.

However, one might think that the argument developed here depends too closely on traditional just war theory, and that its relevance is dependent on assumptions traditionalist scholars make. But as I have mentioned, this argument can be applied to individualist accounts of just war as well, similarly changing what such accounts permit in war as well. As a reminder, individualist accounts of just war reject the independence thesis and suggest that combatants ought not to fight in unjust wars and that they do wrong when they fight in such wars. Specifically, they argue that for unjust combatants almost every action in war will violate the condition of proportionality. This is the case in their view, because no amount of harm to civilians can be imposed in pursuit of an unjust aim.

While it does follow from this that the unjust side is responsible for providing for all persons displaced as a result of their actions, it doesn't follow that the just side is not. One might think that an individualist would assert that when one enters a war unjustly all displacement from such a war is a wrong attributable to the unjust side - after all were the unjust side to do that which is required of them and stop fighting, there would be no displacement. ${ }^{41}$ But this is not what any individualist is likely to argue. After all, even if the just side is fully justified in unintentionally, but foreseeably killing some number of civilians (directly or indirectly) most scholars do think that such civilians' rights (in particular the right to life) are infringed (even if not violated) when they are killed in pursuit of some just aim. That in turn means that if we can limit the harm to civilians in pursuit of our just cause, we ought to, and if my argument above is correct, even those with a just cause have good reasons to staff refugee camps and thus lower the number of civilians they kill (via the increased risk of lethal harm resulting from displacement). This can be explained further by looking at the condition of necessity. If a just combatant can achieve the same aim and lethally harm less civilians they ought to do so.

While there is much more that can be said about how one ought to translate the argument here into individualist just war theory, my sole goal here is to show that having developed the argument within traditionalist theory does not limit the importance or significance of my conclusions to traditional just war theory only.

41 Some have argued points similar to this view. See Davidovic (2017) and Kling (2017). 
In fact, in line with some individualist sensibilities, this argument gives us reasons to reject harsh conceptual and practical distinctions between jus ad bellum, jus in bello and jus post bellum. ${ }^{42}$ One of the consequence of my view is to acknowledge that providing for refugees and internally displaced is not simply a matter of justice post war, it is necessary to meet the jus in bello conditions of proportionality and necessity. Claims that jus in bello greatly affects jus post bellum are not new. For example, not meeting the conditions of, for example, discrimination, and deliberately targeting civilians is not only wrong because it is a violation of their rights, but also because it undermines the ability to achieve reconciliation and long-lasting peace after war and the goal of jus post bellum, if not all of just war theory, is sustainable long-lasting peace. Failing to meet the displacement-sensitive in bello proportionality or displacement-sensitive in bello necessity has significant consequences not only for permissibility of a particular action in war, but also for what is required of us post-war. This suggests that we have a preponderance of reasons to argue that a state entering a war ought to set up displacement infrastructure at the onset of war. The displacement infrastructure should include political and financial assistance for neighboring countries housing refugees, safe migration routes and most importantly staffing and resources for sufficient number of refugee camps in the region.

I have argued in this paper that displacement is a foreseeable near-proximate cause of lethal harm to civilians and is relevant for in bello proportionality and necessity calculi. When the harms resulting from displacement are not included in our analyses, in bello proportionality and in bello necessity are only conditionally met. To meet in bello proportionality and necessity one needs to a) consider displacement in their analyses, b) try to minimize it and in the same way and taking up the same risks as one would for the same increase in risk of direct or kinetic lethal harm and c) knowing that many options will not be available to us once displacement is considered, systematically provide for refugee camps so as to keep the range of strategies which are permissible in war as open as they would have been prior to accepting that displacement is a relevant harm. 43

42 Such harsh distinctions are common, as we have seen, in traditional just war theory. Independence thesis being an instance of that distinction.

43 I am indebted to numerous people for feedback on this paper. I am particularly grateful to the audiences at the Humanitarian Ethics Conference at Birmingham, UK, 2017, International Society for Military Ethics Conference at Crystal City, MD, 2017, and Panel on Responsibility to Refugees at Boulder, Colorado. In addition, I am grateful to Zac Taylor and Yasemin Sari for their feedback and conversations on the issue as well as the anonymous referees for this journal. Finally, I wish to thank Shea Brown, Diane Jeske, Ali Hasan and Amy Weisman for fruitful conversations on the issue. 
Jovana Davidovic

Associate Professor

Philosophy Department

University of lowa

email:jovana-davidovic@uiowa.edu

the global justicenetwork 